\title{
Nursing Practicum in Gynaecology and Obstetrics - Early Influence Possibilities for a Specialty
}

\author{
Pflegepraktikum in der Gynäkologie und Geburtshilfe - \\ frühe Einflussmöglichkeiten einer Fachrichtung
}

Authors

Affiliations
R. Kasch ${ }^{1}$, P. Baum ${ }^{1}$, M. Dokter ${ }^{2}$, M. Zygmunt ${ }^{3}$, J. Wirkner ${ }^{4}$, A. Lange ${ }^{5}$, S. Fröhlich ${ }^{6}$, H. Merk ${ }^{1}$, J. Kasch ${ }^{3}$

The affiliations are listed at the end of the article.

\author{
Key words \\ obstetrics \\ - gynaecology \\ - gynaecological nursing \\ practicum \\ - lack of skilled personnel \\ - feminisation \\ - medical students

\section{Schlüsselwörter} \\ - Frauenheilkunde \\ - Gynäkologie \\ - Pflegepraktikum \\ Gynäkologie \\ - Fachkräftemangel \\ - Feminisierung \\ - Studierende der Medizin
}

Deutsche Version unter: www.thieme-connect.de/ ejournals/gebfra

\subsubsection{5 \\ revised 11.7.2015 \\ accepted $\quad 3.8 .2015$}

Bibliography

DOI http://dx.doi.org/

$10.1055 / \mathrm{s}-0035-1558053$

Geburtsh Frauenheilk 2015; 75 :

1270-1275 @ Georg Thieme

Verlag KG Stuttgart · New York . ISSN 0016-5751

\section{Correspondence}

\section{Dr. med. Richard Kasch, MSc}

Universitätsmedizin Greifswald

Klinik für Orthopädie und

Orthopädische Chirurgie

Ferdinand-Sauerbruch-Straße

17475 Greifswald

kaschr@uni-greifswald.de

\section{Abstract \\ V}

Background: The shortage of skilled personnel is ubiquitous, basic and further training is a key aspect in the recruitment of new medical colleagues. The significance of the nursing practicum in its function as gateway to the gynaecology and obstetrics discipline is practically unexplored.

Methods: In an online questionnaire, medical students in all German faculties were questioned about the practica in their courses. The questionnaire reached 9079 medical students. 149 participants in nursing practica were selectively asked to answer 140 questions. We analysed those students who could, on the basis of their experiences in nursing practica, imagine undertaking an internship (clinical elective) in gynaecology (internship yes "Iy") separately from those who could not or were still undecided (internship no "In" or, respectively, internship perhaps "Ip").

Results: Altogether 149 medical students who participated in a nursing practicum in the gynaecology discipline were selected, of these $94.9 \%$ were female. 92 (61.7\%) of the students replied that, after their gynaecological nursing practicum, they wanted to undertake an internship in gynaecology (Iy); 39 (26.2\%) answered negatively (In) and 18 (12.1\%) were still undecided (Ip). With regard to the parameters gender, age and duration of study, there were no significant differences among the 3 groups ( $\mathrm{X}^{2} 0.83$ ). Besides the didactic and professional quality of the training, Iy also mentioned having had a higher practical orientation. They attained their aims more frequently, were better integrated in the health-care team and acquired more practical competences. Satisfaction with the practicum was evaluated as highest among the Iy.

Discussion: Those students who could imagine taking an internship in gynaecology were seen to be more satisfied with their practica than those participants who declined or were undecided.

\section{Zusammenfassung \\ $\nabla$}

Hintergrund: Der Fachkräftemangel ist allgegenwärtig, die Aus- und Weiterbildung eine Schlüsselstelle in der Rekrutierung von ärztlichen Kollegen. Die Bedeutung des Pflegepraktikums ist in seiner Funktion als Zugangsweg zum Fachbereich Gynäkologie und Geburtshilfe noch weitgehend unerforscht.

Methoden: In einer Onlineumfrage wurden Studierende der Medizin aller deutschen Fakultäten zu ihren Praktika im Studium befragt. Der Fragebogen erreichte 9079 Medizinstudenten. 149 Pflegepraktikanten und -innen auf einer gynäkologischen Station wurden selektiv 140 Fragen gestellt. Wir analysierten die Studierenden, die sich aufgrund der im Pflegepraktikum gemachten Erfahrungen vorstellen konnten, eine Famulatur in der Gynäkologie zu absolvieren (Famulatur Ja „FJ“) getrennt von denen, die dies verneinten oder unentschieden waren (Famulatur Nein „FN“ bzw. Famulatur vielleicht „FV“).

Ergebnisse: Insgesamt 149 Medizinstudierende absolvierten ihr Pflegepraktikum im gynäkologischen Bereich, davon waren 94,9\% weiblich. 92 (61,7\%) Studierende gaben an, nach ihrem gynäkologischen Pflegepraktikum eine Famulatur in der Gynäkologie machen zu wollen (FJ); 39 (26,2\%) verneinten dies (FN) und 18 (12,1\%) waren unentschieden (FV). Hinsichtlich der Parameter Geschlecht, Alter und Studiendauer bestand in den 3 Gruppen kein signifikanter Unterschied $\left(X^{2}\right.$ 0,83). Neben der didaktischen und fachlichen Qualität der Lehre gaben die FJ auch an, einen höheren Praxisbezug gehabt zu haben. Sie erreichten häufiger ihre Lernziele, wurden besser ins Pflegeteam integriert und erwarben mehr praktische Kompetenzen. Die Zufriedenheit mit dem Praktikum wurde am höchsten in der Gruppe FJ bewertet.

Diskussion: Diejenigen Studierenden, die sich vorstellen konnten, eine Famulatur in der Gynä- 
The high proportion of females is an early indicator for a feminisation of the specialty. If necessary this could be countered with the help of nursing management. kologie zu absolvieren, zeigten sich zufriedener mit ihrem Praktikum als die unentschiedenen und ablehnenden Praktikanten. Der hohe Frauenanteil lässt bereits sehr früh eine Feminisierung des Fachbereichs erwarten. Hier könnte mit Unterstützung der Pflegedienstleitung bei Bedarf entgegengewirkt werden.

\section{Introduction}

$\nabla$

In 2003 Thomas Kopetsch published the 2nd edition of the study "Dem deutschen Gesundheitswesen gehen die Ärzte aus (The German Health-Care System is Running Out of Doctors)" [1]. Although the number of freshmen in medicine remains constant, the number of graduates is declining. In 2003 Kopetsch described, somewhat provocatively, that up to $45 \%$ of all new students of human medicine will finally not end up in the medical care profession [1]. Today, a decade later, the problem is more acute than ever before even though the loss of future medical colleagues of $27 \%$ in the year 2010 has gratifyingly declined [2]. In the meantime, much has been done to promote the recruitment of personnel for the medical profession, salaries have been increased, working time regulations have been changed and, last but not least, a stronger representation of the medical fraternity in their negotiating position has been realised [3-7]. The starting point for the changes is to be found above all in a new generation of younger people entering the job market (the so-called generation $\mathrm{Y}$ ) $[4,8-11]$ and the increasing proportion of women within the medical profession [12]. The health-care system must react flexibly to the changing basic and further training wishes as well as the professional expectations of the young doctors and increase its attractiveness $[5,6]$. Specialties such as, in particular, gynaecology and obstetrics (GO), paediatrics and adolescent medicine, and otorhinolaryngology that are principally named by female medical students as preferred specialties for their future medical occupation are among the first that will have to be measured against the changing wishes of the new generation $[11,13,14]$. For this an early orientation is considered to be an important decision criterion for the young generation. In the process, practica, good lectures, receiving a doctor title, and finally the experience gained in the practical year (PY) all play a part. The significance of the nursing practicum in its function as gateway to a specialty is practically unexplored.

This study presents data about the nursing practicum, the first practical training step in medical studies. This study is based on a nation-wide questionnaire survey of medical students on practical training in medical studies in Germany. The presented results reflect the experiences of the students in gynaecological facilities. Against the background of the existing shortage of medical personnel in the field of gynaecology, the authors pose the question as to what influence the first medical practicum - the nursing practicum - in a gynaecological or, respectively, obstetric facility has on the later choice of internship (clinical elective).

Early positive practical experiences in the preferred specialty have a positive effect on the further interest in this discipline [15]. Accordingly, the authors assumed that those students who could imagine taking an internship in the field of gynaecology and obstetrics were more satisfied with their practicum than were participants who had not yet decided or who had decided against the specialty [16]. The results of the present study should provide a stimulus for solution proposals as to if and how one can interest students for the discipline GO and finally to win them as physicians in the specialty.

\section{Methods}

$\nabla$

The working group education (AG Lehre) of the German Society of Orthopaedics and Traumatology (DGOU) in cooperation with the Clinic and Polyclinic for Orthopaedics and Orthopaedic Surgery of the University Hospital Greifswald carried out an online survey from April to the middle of September 2012 with the help of the system EvaSys Education Suite. Medical students and approbated graduates of all Germany medical faculties were questioned about the practical courses during their medical studies (nursing practicum, internships, practical year [PY]). The questionnaire reached a self-selected group of 9079 medical students from a non-randomised selection of the actual basic population.

\section{Questionnaire}

The subgroup - students who completed their nursing practicum on a gynaecological ward - considered in detail in this analysis were selectively asked 140 questions. Selected results from the data set on the nursing practicum are presented. The question format consisted of predefined simple answers, multiple answers and questions with a Likert scale from 1 (e.g., "I disagree fully") to 5 (e.g., "I agree fully"). Free-text answers were also possible.

The questionnaire comprised a general section (with questions about personal details, academic progress, preferred specialty, reasons for the choice of subject) and several special sections that were to be answered according to academic progress and practica (in this case nursing practicum). In the context of the nursing practicum, questions were posed regarding integration in the team, learning practical skills, didactics, acquisition of competences and overall satisfaction.

A fundamental parameter of the study is a comparison of the answering behaviour of the participants after the nursing practicum with regard to their decision to choose an internship again in the field of gynaecology and obstetrics. In all evaluation scales the answers 1 and 2 were grouped together as "unsatisfactory", 3 as "undecided" and the answers 4 and 5 as "satisfactory". To answer the above-mentioned issues those students who could, after the nursing practicum, imagine choosing an internship in gynaecology (internship yes "Iy") were analysed separately from those who decided against (internship no "In") or who were undecided (internship perhaps "Ip"). Mean values (M) given here thus refer to the answering behaviour in the respective groups (Iy, Ip, In).

\section{Statistics}

Statistical analyses were performed with the help of Sphinx Plus Survey and SPSS 22.0. (IBM Corp., Armonk, USA). Besides descriptive statistics, the $\mathrm{X}^{2}$ test was used for frequencies, for the individual items ( Table 2 ) univariate ANOVAs with the between-subject factor groups (Iy vs. Ip vs. In) were performed. 


\section{Results}

$\nabla$

Altogether 149 medical students reported that they had completed their nursing practicum on a gynaecological or obstetric facility, $94.9 \%$ of them were female. Analysis of age revealed that the majority of them (67.2\%) were between 20 and 23 years of age at the time of questioning (see also 0 Table 1$) .92(61.7 \%$ ) of these students stated that they wanted to take an internship in gynaecology on account of their gynaecological nursing practicum (Iy); 39 (26.2\%) did not want to do this (In) and 18 (12.1\%) were undecided (Ip). With regard to the parameters gender, age and duration of study, there were no significant differences between the groups $\left(X^{2}\right.$ 0.83). At the time of questioning the 149 medical students were enrolled in 33 of the 36 German medical faculties.

\section{Learning practical skills}

Among the participating students $88.3 \%$ stated that they had gained a good or very good impression of the tasks and competences of nursing personnel during their nursing practica. This was true for the gained confidence and practice in the performance and maintenance of hygiene measures (79.5\%) as well as confidence and practice in monitoring vital parameters (86.3\%). Altogether, $65.5 \%$ gained confidence and practice in the performance of basic care measures. Univariate analyses of each of the acquired skills did not reveal any significant group differences ( Table 2). However a trend was apparent that those students who were planning for an internship in GO had acquired more confidence in the monitoring of vital parameters than those who later did not want to take an internship in GO.

\section{Teaching in nursing practicum}

The didactic quality of nursing practica on gynaecological wards was assessed as good or very good by merely $23.4 \%$ of the students. The concept and structure was assessed as being rather negative $(\mathrm{M}=2.43)$, as was the poor contact with the instructors $(\mathrm{M}=2.50)$ and lack of bedside teaching $(\mathrm{M}=2.74)$ ( $\bullet$ Fig. 1$)$. Only about one third of the participants stated that they had achieved the learning goals of the nursing practicum.

Medical students who later intended to take a gynaecological internship assessed the professional and didactic quality as being significantly better than did those who subsequently did not plan
Table 1 Sociodemographic data of the participants.

\begin{tabular}{|c|c|}
\hline & $\begin{array}{l}\text { Participants in gynaecological } \\
\text { nursing practica } \\
n=149\end{array}$ \\
\hline Age in years (SD) & $23.2(3.7)$ \\
\hline \multicolumn{2}{|l|}{ Gender } \\
\hline female & $94.9 \%$ \\
\hline male & $5.1 \%$ \\
\hline \multicolumn{2}{|l|}{ Family status } \\
\hline s single & $44.5 \%$ \\
\hline D solid partnership & $50.7 \%$ \\
\hline married & $4.8 \%$ \\
\hline Parents in medical profession & $17.5 \%$ \\
\hline Children & $4.2 \%$ \\
\hline
\end{tabular}

$\mathrm{SD}=$ standard deviation

to take an internship in gynaecology (professional quality: $\mathrm{p}<0.01$; didactic quality: $\mathrm{p}<0.05$ ). In addition, they reported to have achieved the learning goals to a higher extent (Iy vs. In: $\mathrm{p}<0.05$ ) and to have experienced more practical orientation in the nursing practicum (Iy vs. In: p < 0.01). In comparison to the still undecided participants, the Iy group exhibited significantly better ratings only in the item practical orientation ( $\mathbf{F i g . 1}$ ).

\section{Acquisition of competences}

The acquisition of practical competences ( Table 2) was assessed as good or very good by a majority of the students (69.1\%). The same was true for learning to work independently (63.8\%) and gaining cooperation and team working abilities (56.4\%). However, $81.8 \%$ of the participants considered the acquisition of professional problem-solving and analytical abilities to be inadequate as did $80.5 \%$ the acquisition of interdisciplinary knowledge. The Iy group assessed not only the acquisition of practical competences $(\mathrm{p}=0.01)$ but also the team work $(p=0.009)$ significantly better than did the In group. All further comparisons did not reveal any significant differences.

\section{Satisfaction}

$46.3 \%$ of all participants reported that they were on the whole satisfied with the nursing practica whereby the group Iy gave a

Table 2 Internship in gynaecology. Evaluation of the nursing practicum and group differences.

\begin{tabular}{|c|c|c|c|c|c|}
\hline \multirow[b]{2}{*}{ Item } & \multicolumn{5}{|c|}{ Internship in gynaecology/obstetrics } \\
\hline & No & Perhaps & Yes & $\mathbf{F}$ & Sig. \\
\hline \multicolumn{6}{|l|}{ Practical skills } \\
\hline impression of nursing tasks & 4.256 & 4.222 & 4.337 & 0.210 & 0.881 \\
\hline confidence in performance of hygiene measures & 3.846 & 4.222 & 4.185 & 1.933 & 0.148 \\
\hline confidence in basic care & 3.410 & 3.722 & 3.780 & 1.353 & 0.262 \\
\hline - confidence in measuring vital parameters & 4.158 & 4.222 & 4.511 & 2.452 & 0.09 \\
\hline - knowledge of normal values for vital parameters & 4.282 & 4.389 & 4.522 & 0.953 & 0.388 \\
\hline \multicolumn{6}{|l|}{ Acquisition of competences } \\
\hline - practical competences & 3.462 & 3.778 & 4.033 & 4.795 & 0.010 \\
\hline - independent working & 3.487 & 3.333 & 3.728 & 1.288 & 0.279 \\
\hline - analytical skills & 2.205 & 2.611 & 2.593 & 1.827 & 0.165 \\
\hline - interdisciplinary knowledge & 2.333 & 2.667 & 2.630 & 1.117 & 0.330 \\
\hline - specialist knowledge & 2.667 & 2.889 & 3.054 & 1.981 & 0.142 \\
\hline team work & 3.128 & 3.389 & 3.793 & 4.873 & 0.009 \\
\hline
\end{tabular}

Data are average values. Significant analyses are printed in boldface. 
Training in nursing practicum

a
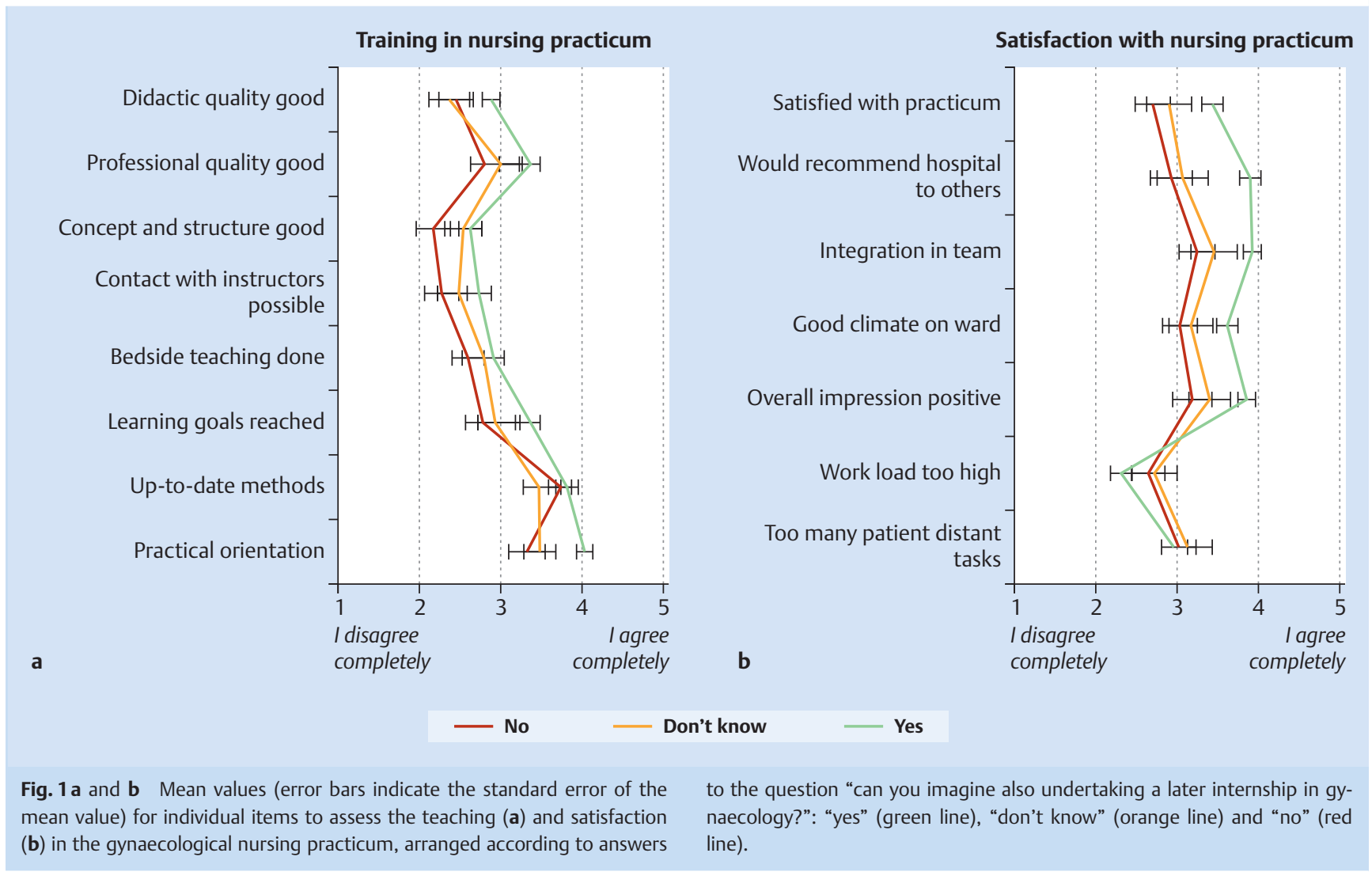

Satisfaction with nursing practicum

significantly better evaluation of the nursing practica than did the In group ( $p=0.002$; $\boldsymbol{O}$ Fig. 1 ). This is also reflected in the higher willingness to recommend the clinic/ward in which they undertook the nursing practicum to others (Iy vs. In $p=0.000$; Iy vs. Ip $p=0.016$ ). The parameters on integration into the hospital routine proved to be very important for the decision to undertake the next practicum, i.e., the internship, in the same, namely gynaecological, specialty. Altogether $61.7 \%$ of the participants stated that their integration into the health-care team was good or, respectively, very good. In the subgroup Iy the rate of not well integrated participants was significantly lower than that in the In subgroup ( $p=0.002)$. A good or very good ward climate was confirmed by $54.3 \%$ in group Iy, in contrast to only $43.9 \%$ of group In who assessed the ward climate as good or very good. Here also there was a significant group difference (Iy vs. In: $\mathrm{p}=0.011$ ). Altogether, $81.1 \%$ of the participants did not consider the work load to be too high and $65.5 \%$ of the participants did not have to carry out too many patient-distant tasks. Those participants in nursing practica who could imagine taking an internship in the same discipline had a more positive total impression than those who did not want to do an internship in GO ( $p=0.003)$.

\section{Discussion}

$\nabla$

The shortage of qualified personnel is ubiquitous and training plays a key role in the recruitment of young medical colleagues. The nursing practica on gynaecological wards analysed by us are characterised by a predominantly female gender ratio and, even at such an early stage in medical education, this leads us to expect a feminisation of the specialty. Two of three students could imagine also taking an internship in gynaecology on the basis of the good experience in the nursing practicum. Besides the didactic and professional quality of the training, the high practical orientation and the acquisition of practical competences, the better achievement of learning goals and integration in the health-care team all played a major role. These parameters were shown to be mainly responsible for the fact that satisfaction with the practicum was assessed positively.

The aim of the nursing practicum is to make the students familiar with the usual daily routine of nursing care and to introduce them to the operation and organisation of a hospital (regulations for medical training, ÄAppO 2002, §6). Furthermore, this first clinical practicum offers much more, for many medical students it represents the first longer and formative contact with patients and a hospital. In the authors' opinion this sensitive first contact cannot be rated high enough since it gives the discipline a possibility not only to inspire potential new colleagues but also to discourage them. The present nation-wide overview of opinions of medical students on nursing practica shows which parameters are important to ensure that participants remain "loyal" to the discipline. The interviewed participants judged the acquisition of practical abilities to be very positive on the whole, a sign that the stated objectives of the ÄAppO have been fulfilled. Even so, important recommendations for action can be deduced for the specialty to appear as an attractive employment proposition from the students' point of view. Thus, integration in the nursing and medical team as well as close contact with the instructors is at the top of the list of key factors for a successful education. Already the high proportion of females (94.9\%) who have completed the GO nursing practica confirms that even at the start of medical education GO as a specialty is highly preferred by fe- 
males. A survey of medical students with regard to their future choice of specialist medical training revealed similar results. Significantly more women than men would choose the GO discipline $[11,17-20]$. The proportion of female doctors in the GO field in 2009 was already $56 \%$ and the proportion of females receiving certification as medical specialists in the GO field was the highest at 76\% [2]. In 2013 the number of certifications as medical specialists in the field of gynaecology and obstetrics amounted to $5.8 \%$ of all specialist certifications with a female proportion of $84 \%$ [21]. This represents an increase of $8 \%$ within the past 4 years. It remains to be seen whether or not this number will remain so high in the coming years or, respectively, if it will increase further and if or how it can be influenced.

In the preclinical routine students are in part arbitrarily assigned to the respective specialties by the nursing management. Since, in GO the students learn their first nursing-medical steps on a female patient collective, it is perhaps more natural to assign female students to these nursing practica. Thus it may be assumed, in the case of central assignment systems that our future female colleagues come into contact with our discipline more frequently. This possible early selection could have an impact on the above average female proportion in the specialty [15]. Unfortunately, due to the small number of male participants $(n=8)$ in our data set, no robust deductions on their evaluation of the nursing practicum are possible. Furthermore, a limitation of our results is that they originate from freshmen whose reasons for choosing a nursing practicum on a gynaecological ward could have been very heterogeneous and also were not addressed in the questionnaire. This means that we cannot assume that all students had a professional interest in the choice of practicum but instead could have been arbitrarily assigned to the respective wards. Against this background the evaluation of our results leads to the recommendation for an early involvement of the future colleagues.

Medical studies are often accused of not being able to convey the competences needed for the later professional life of a physician. The students often experience them as being a patient distant, theoretical, overloaded collection of unrelated multiple choice oriented disciplines [22]. On the other hand, medical practica promote the acquisition of practical skills at the bedside. Students consider the practical activities to be extremely important as was demonstrated by Dettner et al. in 2010 with the help of a questionnaire among students in the PY [16].

Besides the good evaluation of the acquisition of practical skills, it is apparent from the present analysis that one-third of the students reported that they had gained only an inadequate confidence in performing the general care of patients. The reason for this could be the lower basic care needs of gynaecological patients as well as the also strongly reduced demands for basic care in obstetric wards, thus apparently the acquisition of practical skills is an important parameter for satisfaction in nursing practica (Spearman's correlation coefficient $=0.51, p=0.01$ ). Other reasons for dissatisfaction were the insufficient didactic quality of the training, the lack of bedside training as well as lack of contact with the instructors, there is room for improvement here to make the practicum tasks fairer and more attractive from the trainee's and later trainer's points of view. Young ambitious employees at the start of their professional careers will seek an employer who offers them good opportunities for development, the promise of personal motivation and establishes personal contacts [23]. A successful employer is characterised by an open personnel culture as well as an interest in the further development of trainees $[22,23]$.
On the basis of experience gained in the nursing practicum, the answers with regard to the interest in wanting to do an internship in gynaecology/obstetrics was of particular interest since it could be assumed that the student's early (at the beginning of the medical studies) experience with the discipline could have had an influence on the later choice of specialist medical training [14]. Accordingly this poses the question as to how the nursing practicum in GO can be improved.

We have shown that those questioned students who evaluated the training positively could imagine taking an internship in GO. They reported that they had gained more practical competences, they assessed team work more positively, they were integrated in the nursing team and finally they expressed a high satisfaction with the practicum. It is seen that the acquisition of practical competences is associated with a significantly higher satisfaction with the nursing practicum ( $\bullet$ Fig. 1). The degree of satisfaction correlates positively with the intention to take a later internship in GO. Altogether, the presented differences emphasise that a student-oriented training in the nursing practicum induces a higher and continuing interest in the discipline.

The Commission "Professional Perspectives in Gynaecology" (Kommission "Berufsperspektiven in der Frauenheilkunde") and the Young Forum of the Germany Society for Gynaecology and Obstetrics (Junges Forum der Deutschen Gesellschaft für Gynäkologie und Geburtshilfe) have already undertaken positive and comprehensive measures, e.g., in the form of a 15-minute presentation, to increase interest in the discipline [24]. Thus it is intended on the basis of the highly positive resonances from the students' side to integrate this in the nation-wide introductory lectures on gynaecology. Furthermore, the authors consider it to be advisable already early in the course, for example in the nursing practicum, to begin with the support of potential colleagues. For this reason they suggest that the teaching content of the nursing practicum be set out in the form of a learning catalogue and be implemented accordingly [25]. A logbook offers not only the students but also the instructors many more chances as it formulates a minimum structure. The thus achieved commitment, planning security and perceptibility of a structure training would be much appreciated by the students $[8,11,18]$.

In addition, we have shown that personal contact with the instructors is very important for the students. Accordingly, it would be advantageous in analogy to the already established PY representatives to also implement representatives for the nursing practica. Especially for those disciplines with a lack of new recruits or unbalanced gender ratios such as GO $[10,13,26]$ an early commitment of students to the specialty can be achieved through a solid training scheme. Furthermore, it must be realised that the greatest part of the teaching in the nursing practica is done by nurses. In order to achieve a sustainable improvement the nursing personnel must be specifically included in the discussions. Integration of nursing personnel must be followed with the targets of preparing concepts for teaching and at the same time to increase awareness of the importance of the nursing practica.

\section{Acknowledgements \\ $\nabla$}

The authors thank the German Society for Orthopaedics and Traumatology (Deutsche Gesellschaft für Orthopädie und Unfallchirurgie [DGOU]) for supporting the study with a donation of $10000 €$. The DGOU as sponsor was not involved in the data acquisition, analyses or composition of this contribution. 


\section{Conflict of Interest}

$\nabla$

None.

\section{Affiliations}

${ }^{1}$ Klinik für Orthopädie und Orthopädische Chirurgie, Universitätsmedizin Greifswald, Greifswald

2 Institut für Anatomie, Universitätsmedizin Greifswald, Greifswald

${ }^{3}$ Klinik und Poliklinik für Frauenheilkunde und Geburtshilfe,

Universitätsmedizin Greifswald, Greifswald

${ }^{4}$ Klinik für Innere Medizin A, Universitätsmedizin Greifswald, Greifswald

${ }^{5}$ Klinik für Kinder- und Jugendmedizin, Universitätsmedizin Greifswald, Greifswald

${ }^{6}$ Klinik für Orthopädie, Universitätsmedizin Rostock, Rostock

\section{References}

1 Kopetsch T. Dem deutschen Gesundheitswesen gehen die Ärzte aus! Studie zur Altersstruktur- und Arztzahlentwicklung. Berlin: Bundesärztekammer und Kassenärztliche Bundesvereinigung; 2003

2 Kopetsch T. Dem deutschen Gesundheitswesen gehen die Ärzte aus! Studie zur Altersstruktur- und Arztzahlentwicklung. Berlin: Bundesärztekammer und Kassenärztliche Bundesvereinigung; 2010

3 Schmidt CE, Moller J, Schmidt $K$ et al. Generation 55+: Leadership and motivation of generations in hospitals. Anaesthesist 2012; 61: 630639

4 Adler G, $v$ d Knesebeck JH. [Shortage and need of physicians in Germany? Questions addressed to health services research]. Bundesgesundheitsblatt Gesundheitsforschung Gesundheitsschutz 2011; 54: 228-237

5 Hancke $K$, Igl W, Toth B et al. Work-life balance of German gynecologists: a web-based survey on satisfaction with work and private life. Arch Gynecol Obstet 2014; 289: 123-129

6 Buxel H. Arbeitsplatz Krankenhaus, Was Ärzte zufriedener macht. Dtsch Ärztebl 2013; 110: A494-A498

7 Montgomery FU. Arztberuf attraktiver gestalten, sonst bricht die Versorgung ein. In: Bundesärztekammer, Hrsg. Pressekonferenz am 3 September 2010 in Berlin. Studie zur Altersstruktur- und Arztzahlentwicklung; 2010

8 Schmidt CE, Moller J, Schmidt K et al. Generation Y: recruitment, retention and development. Anaesthesist 2011; 60: 517-524

9 Heinz A, Jacob R. [Medical students and their career choices. Preferred specialty, where and how to work]. Bundesgesundheitsblatt Gesundheitsforschung Gesundheitsschutz 2012; 55: 245-253

10 Osenberg D, Huenges B, Klock M et al. Wer wird denn noch Chirurg? Zukunftspläne der Nachwuchsmediziner an deutschen Universitäten. Chirurg 2010; 6: 308-315

11 Gibis B, Heinz A, Jacob R et al. Berufserwartungen von Medizinstudierenden. Dtsch Ärztebl 2012; 109: 327-332

12 Aßmann S, Schneiderat G, Balck F. Warum Medizin - Unterscheiden sich männliche und weibliche Studierende in ihren Beweggründen für ein Medizinstudium und in ihren beruflichen Plänen? In: Brähler E, Alfermann D, Stiller J, Hrsg. Karriereentwicklung und berufliche Belastungen im Arztberuf. Göttingen: Vandenhoeck \& Ruprecht; 2008: 73-83
13 Blum K, Löffert S. Ärztemangel im Krankenhaus - Ausmaß, Ursachen, Gegenmaßnahmen - Forschungsgutachten im Auftrag der Deutschen Krankenhausgesellschaft. Düsseldorf: Deutsches Krankenhausinstitut; 2010: 142

14 Gensch $K$, Waltenberger M. Entwicklung der ärztlichen Versorgung in Bayern unter Berücksichtigung des steigenden Anteils an Ärztinnen. München: Bayrisches Staatsinstitut für Hochschulforschung und Hochschulplanung; 2006

15 Schäfer H-M, Sennekamp M, Gilbert K et al. Kann das Blockpraktikum Allgemeinmedizin Studierende in ihrer Wahrnehmung der Berufszufriedenheit von Hausärzten beeinflussen? Can an internship in family medicine influence students' perceptions of professional satisfaction among primary care doctors? Zeitschrift für Allgemeinmedizin 2010; 83: 109-112

16 Dettner S, Kuhlmey A. Studienzufriedenheit und berufliche Zukunftsplanung von Medizinstudierenden - ein Vergleich zweier Ausbildungskonzepte. In: Schwartz F, Angerer P, Hrsg. Arbeitsbedingungen und Befinden von Ärztinnen und Ärzten - Befunde und Interventionen. Köln: Deutscher Ärzte-Verlag; 2010: 103-115

17 Gedrose B, Wonneberger C, Junger J et al. [Do female medical graduates have different views on professional work and workload compared to their male colleagues? Results of a multicenter postal survey in Germany]. Dtsch Med Wochenschr 2012; 137: 1242-1247

18 Götz K, Miksch A, Hermann K et al. Aspirations of medical students: "planning for a secure career" - results of an online-survey among students at five medical schools in Germany. Dtsch Med Wochenschr 2011; 136: 253-257

19 Kruschinski C, Wiese B, Eberhard J et al. Attitudes of medical students towards general practice: Effects of gender, a general practice clerkship and a modern curriculum. GMS Zeitschrift fur medizinische Ausbildung 2011; 28: Doc16

20 Stiller J, Busse C. Berufliche Karriereentwicklung von Ärztinnen und Ärzten - Die ersten 4 Berufsjahre. In: Brähler E, Alfermann D, Stiller J, Hrsg. Karriereentwicklung und berufliche Belastungen im Arztberuf. Göttingen: Vandenhoeck \& Ruprecht; 2008: 140-161

21 Osterloh F. Ärztestatistik: Mehr Ärztinnen, mehr Angestellte. Dtsch Arztebl 2014; 111: A-672/B-580/C-560

22 Füllgraf $O$, Debatin J. Flaschenhals Mitarbeiter. In: Lohmann HPU, Hrsg. Mitarbeiter händeringend gesucht: Personalkonzepte sichern Überleben. Heidelberg: medhochzwei; 2011: 185

23 Wagner R, Wittmann M, Ries S. Vorsicht vor Stereotypen - was die Generation Y motiviert. Wirtschaftspsychologie aktuell 2012; 32-38

24 Lermann J, Engeln T, Vetter L et al. Berufsperspektiven in der Gynäkologie - wie geht es los, wie geht es weiter? Geburtsh Frauenheilk 2014; 74: 1066

25 Froehlich $S$, Obertacke $U$, Ruesseler $M$ et al. An educational skills programme for undergraduate training in orthopaedic and trauma surgery. Z Orthop Unfall 2011; 149: 568-574

26 Jacob R. Berufsmonitoring Medizinstudenten. 2. Welle 2014 - Ergebnisse einer bundesweiten Befragung. Berlin 2014. Online: http:// www.kbv.de/html/5724.php; last access: 07.11.2014 